\title{
A Biblical Argument for Veganism
}

\author{
Talia Raphaely, Curtin University, Australia* \\ Dora Marinova, Curtin University, Australia \\ (iD https://orcid.org/0000-0001-5125-8878
}

\begin{abstract}
This paper argues that veganism is the ideal diet for a religious and spiritual Biblically endorsed lifestyle. Both Christians and Jews are guided by the Old Testament's injunctions and writings, which equally support a vegan lifestyle. Areas of discussion include G-d's first intention, the Biblical goals of preservation of health, compassion for animals, equitable sharing of food with the hungry, environmental protection and wellbeing, including conservation of resources, preserving and healing the world, seeking and pursuing peace. It concludes that in light of the animal, human, and environmental impacts of modern livestock production and consumption, veganism is the moral, ethical, and spiritually-supported choice for those who subscribe to lifestyles led and inspired by the stories, interpretations, commentaries, injunctions, and guidance of the Hebrew Bible. It also offers spiritually directed followers a sacred way to actively, yet non-violently, oppose daily human, animal, and environmental welfare violations caused by meat production and consumption.
\end{abstract}

\section{KEYWORDS}

Animal, Compassion, Food, Hebrew, Humanity, Jew, Judaism, Noah, Rabbi

\section{INTRODUCTION}

In 2019, the number of Jews in the world was estimated at 14.7 million, with $45 \%$ (or 6.8 million) of them living in Israel (Australian Jewish News, 2019). In that same year, USA had the secondlargest Jewish population of 5.7 million followed by France $(450,000)$, Canada $(392,000)$ and United Kingdom 292,000). The remaining Jewish diaspora stretches across the entire globe, including 116,000 Jews living in Australia. These figures refer to the core Jewish population, namely the people who identify themselves as Jews above anything else. However, the total Jewish population was estimated at 23.5 million in 2018 when people with mixed background (e.g. only one Jewish parent), those who live in households with Jews and people who are allowed to migrate to Israel under the country's Law of Return, are added (DellaPergola, 2018). Although many associate Jewish history with the Holocaust (United Nations, 2020), there is limited understanding about the religious and socio-cultural characteristics that define this large population group.

Judaism is one of the oldest religions in the world. In this article, we specifically examine some of the biblical arguments about veganism as presented in the Jewish texts and teachings. Although most Jews nowadays consume meat, rabbis across the world are increasingly supporting 
veganism (Raphaely \& Myerson, 2019). There are two main reasons for doing this. The first, and most important driver, is the fact that widespread consumption of animal-based foods, mainly in the Western world (where the majority of modern Jews live), is transgressing all reasonable boundaries and exploiting the natural resources of the planet contributing towards bleak predictions about a future severely impacted by climate change, biodiversity loss and uncontrollable communicable and non-communicable diseases (Willett et al., 2019). Second, and a mainly spiritual driver, is the desire to explicitly show how Judaism approaches the consumption of food. Of particular relevance to the question of spirituality, it is worth noting that religions are also guiding human behaviour - almost everything a Jewish person does can become an act of faith and worship. Thus, Jews do not seek only to obey the letter of the law - the particular details of each of the Jewish regulations and mandates - but the spirit of it too. This means that practicing Jews try to bring holiness into everything that they do, by doing it as an act that praises $\mathrm{G}^{-} \mathrm{d}^{1}$ and honours everything that G-d has done. For such a person - the whole of their life, including the consumption of food - becomes an act of worship. Judaism is thus a faith of action and Jews believe they should contribute to the overall holiness of the world. It is also worth noting that Jewish life is very much linked to a community with many required activities. For example, the Jewish prayer books use "we" and "our" in prayers where some faiths would use "I" and "my". This also encapsulates Jewish religious life as being contextualised within a global community.

\section{BACKGROUND}

Classical Jewish law neither explicitly requires nor prohibits meat consumption. It does however demand, inspire and compel mindful, conscious eating via a myriad of complex, inter-relating laws, injunctions, sanctions and principles. These complex directions, restrictions and commands have stimulated centuries of religious, spiritual and philosophical debate by Judaism's most eminent rabbis, sages and teachers about the consumption of animal flesh authoritatively documented in ancient (pre-Christian era), middle ages and contemporary manuscripts. These tombs require lifetimes of dedicated study and any in-depth analysis is beyond the scope of this paper. Discussion will thus be limited to four key Jewish texts:

1. The Torah or Pentateuch (The five Books of Moses; Genesis, Exodus, Leviticus, Numbers, and Deuteronomy).

2. The Meforshim and Perushim ("commentators" and "commentaries") particularly medieval French rabbi Shlomo Yitzchaki known as Rashi (1040 -1105), medieval Jewish philosopher and influential Torah scholar Maimonides known as Rambam (1138-1204), and Rabbi Abraham Isaac Hacohen Kook (the first chief rabbi of pre-state Israel, and one of the most outstanding Jewish philosophers of the twentieth century henceforth referred to as Rabbi Kook).

3. The Talmud (the oldest postbiblical codification of Jewish oral laws compiled by scholars over two centuries).

4. The rabbinic Responsa (decisions and rulings regarding Jewish law or halacha, and which function as precedents starting from the 6th century) and in particular the Shulchan Aruch (Code of Jewish Law) written by Rabbi Joseph Caro (1488 -1575).

The discussion to follow illustrates that Judaism offers very specific guidance and instructions regarding caring for animals, others, one's health and the environment. Modern western production and consumption of livestock products contravene all these commands, essentially negating any permissions to consume meat. Veganism clearly emerges not only a life-affirming spiritual process that increases personal health, sustainability and wellbeing of the earth and all who dwell here, but also as the only way to adhere to the broader collection of Jewish laws and commandments. 


\section{HASHEM'S INTENTIONS REGARDING HUMANITY'S ORIGIN AND DESTINY}

Conclusive discussion about the intentions of Hashem (the Hebrew term for G-d) is beyond human capacity. Jews however, believe that from creation Hashem intended humankind be vegetarian based on G-d's directive in Eden that all creatures adopt an entirely plant-based diet: "And G-d said: Behold, I have given you every herb yielding seed which is upon the face of all the earth, and every tree that has seed-yielding fruit- to you it shall be for food" (Genesis 1:29). Straight after issuing this commandment, Hashem described creation as tov me-od (very good), the only time in the whole creation narrative that work is described as tov me-od instead of merely as tov (good) and this commandment (to eat fruit from the trees and the plants of the field) is repeated twice, in alternative forms, in Genesis 2:16 and 3:18. Thus Adam and Eve, the original couple and parents of the human race, according to biblical tradition, were indisputably vegan. Rashi elaborates on Genesis that "G-d did not permit Adam and his wife to kill a creature and to eat its flesh, but all alike were to eat herbs" (Rashi in Jewish Virtual Library, 2020, n.p.) and most, if not all, reputed Torah scholars and commenters agree the original diet in Eden was without animal products of any kind (including eggs and dairy products) indicating Hashem intended people to be vegan. Further, in Deuteronomy (8:7-9), the earth's bounty is described in strictly vegetarian terms: "For the Lord thy G-d bringeth thee into a good land, a land of brooks of water, of fountains and depths that spring out of valleys and hills; a land of olive oil and honey; a land wherein thou shalt eat bread without scarceness, and thou shalt not lack any thing in it".

It is also undisputed amongst both past and present Jewish religious authorities that veganism is the diet to which Jews (and all of humankind) will return with the coming of the Messiah. This is evidenced by the prophecy of Isaiah: "And the wolf shall dwell with the lamb, and the leopard shall lie down with the kid; and the calf and the young lion and the fatling together; and a little child shall lead them. And the cow and the bear shall feed; their young ones shall lie down together and the lion shall eat straw like the ox. They shall not hurt nor destroy in all My holy mountain." (Isaiah 11: 6-9). Even animals who would normally prey on each other, will become vegan, dwelling peacefully together under the shepherding of a mere child - the Messiah - who is still to come. In times to come thus, Hashem's original intention of creation is restored and renewed.

Judaism's two most well-known portrayals of an ideal world - namely the Garden of Eden in the story of creation, and the messianic prophecies of Isaiah - are thus both linked to a completely vegan world. However, this is not how things are now.

\section{WHAT HAPPENED BETWEEN CREATION AND NOW}

The very first commandment given to humanity was about food: "And the Lord G-d commanded the $\operatorname{man}^{2}$, saying, 'You may freely eat of every tree of the garden; but of the tree of knowledge of good and evil you shall not eat, for in that day that you eat of it you shall die"' (Genesis 2:16-17). Modern commentators suggest the reason this is the first and most prominent commandment is because there is nothing more personal than what we choose to put into our mouths. Yet a widely-felt emotional belief prevails that no-one has the right to regulate another's diet, that this is a deeply personal and individual decision - the violation of which leaves one feeling invaded, diminished, demoralised. Thus, this commandment has been interpreted as a relationship test between Hashem and his people in the Garden of Eden. Would Adam and Eve respect G-d's right to regulate their lives even to the point of restricting their diet? Famously, they couldn't and didn't, failing this initial and crucial test and illustrating how challenging it is to adhere to idealistic and philosophical ideals.

Thus, traditionally, began the humanity's decay into the greed and gluttony still evident today. By Noah's time already, "humanity was eating limbs torn from living animals" (Schwartz, 2001, p. 15) and cannibalism prevailed. "Now the earth was corrupt in the sight of G-d, and full of violence" (Genesis 6:12) and so G-d said to Noah: "The end of all living creatures has come before Me, because through 
them the earth is full of violence. Now behold, I will destroy both them and the earth." However, Noah was considered one of the few remaining righteous, so "the Lord said unto Noah, Come thou and all thy house into the ark; for thee have I seen righteous before me in this generation..." (Genesis 7:1-21), and upon surviving the inundation, Noah was told, "every moving thing that lives shall be yours to eat; like the green vegetation, I have given you everything" (Schwartz, 2001, p. 15).

Up until the time of Noah, meat consumption was neither referred to, nor permitted. It is only after The Flood that Noah and his children were explicitly given permission to eat the flesh of animals. What caused Hashem's change of mind? Why after cleansing the earth was Noah and his descendants, given permission to eat meat?

Permission occurred immediately after The Flood, when humanity had sunk to such a low point of immorality that G-d deemed it necessary to eradicate life and start over. Sages agree the human corruption and violence leading to The Flood included humanity's appetite for flesh. After the deluge, G-d promised never again to unleash a flood of such proportions but, to keep that promise, a disappointed Divinity had to lower standards for humankind's behaviour and make some concessions including permission, under strict regulations, to eat flesh rather than harbour a forbidden appetite that would again sow violence and corruption. According to Rabbi Kook, people had sunk to such a low level of spirituality that if denied the right to consume meat, they might eat the flesh of human beings due to their inability to control their lust for flesh. So, permission to eat meat was a concealed reproach and qualified command that the day will come when people will detest the eating of flesh of animals because of a moral loathing (Green, n.d.).

Throughout Jewish texts flesh foods are mentioned with distaste and associated with lust, materialism and lack of control over one's appetite for meat. "It is inconceivable that the Creator who had planned a world of harmony and a perfect way for man to live should, many thousands of years later, find that this plan was wrong" (Kook in Pick, n.d., p. 2). Rabbi Kook explains a merciful G-d would never institute a permanent law permitting the killing of animals for food (in Green, n.d.) and any permissions for Jews to eat meat is merely a temporary, transient concession to humanity's weak nature, a transitory grudging concession and managed compromise until a "brighter era" is reached and people returned to a vegan diet (Sears, 2014).

Clearly, the prohibition regarding eating meat was temporarily suspended but "never annulled ....and in the Messianic Age, the prohibition [will] come into force once more" (Cassuto Commentary on the Book of Genesis, Part One, pp. 58-59.). Meat consumption is thus linked to human degeneracy and the need for a strict code of conduct. Conversely veganism is associated with the idyllic Garden of Eden and the ideal world to return in the Messianic Age - that time in the world to come when there will be universal peace and love without any evil.

\section{COMPASSION FOR ANIMALS}

Judaism strictly forbids animal cruelty or infliction of pain on animals. This prohibition is a fundamental and core Jewish value known as tza'ar ba'alei chayim (literally "suffering of living creatures") and derives from the biblical law requiring people to assist in unloading burdens from animals (Exodus 23:5). Tza'ar ba'alei chayim is "a rule laid down by our sages that it is directly prohibited in the Torah to cause pain to an animal..." (Hertz, 1981, p. 673).

Attention to animal welfare is also mentioned in the Fourth of the Ten Commandments which designates the Sabbath as a day of rest for man and his work animals alike: "Observe the Sabbath day...In it thou shalt not do any manner of work, thou, nor thy son, nor thy daughter, nor thy cattle (which is understood as applying to all animals), nor thy stranger that is within thy gates..." (Deuteronomy 5:12-14).

Throughout Jewish texts, people are commanded to be compassionate to animals. The Book of Proverbs asks that all animals are treated with compassion as G-d is merciful to all his creatures: "A 
righteous man regardeth the life of his beast" (Proverbs 12:10). The Book of Psalms praises a G-d who is merciful to man and beast: "O Lord, thou preservest man and beast" (Psalm 36:6-7).

The story of Balaan in the Book of Numbers (Numbers 22:23-34) tells how G-d threatened to kill Balaan in order to save the animal he was beating, asking "Wherefore has thou smitten thine ass?" Another important text, the Shulchan Aruch (Code of Jewish Law), written by the authority Rabbi Caro, contains several sections on the protection of animals, including sparing them from burdensome or annoying labour, assuring them of rest on the Sabbath, providing them with sufficient food and alleviating their suffering (Caro in Goldin, 1927, vol. 2, p. 87).

It is forbidden in the Torah to hurt any living creature. On the contrary, it is a duty to save, help and protect any living creature (even if that creature does not have an owner): "When horses which are drawing ... a cart comes to a rough place or to a high hill and they cannot draw the cart without help, it is a religious duty to help... because of the precept forbidding cruelty to animals, lest the owner smite them to make them draw more than their strength permits" (Caro in Goldin, 1927, vol. 2, p. 87).

In the Responsa literature, hunting is deplored as wasteful and unnecessarily cruel. Hunting for sport is biblically expressly forbidden and hunting animals is something shameful.

According to the Talmud, it is permitted to slay wild animals only when they invade human settlements. To pursue them in the woods, their own dwelling place, when they are not invading human habitations, is prohibited and pursuit means simply following the desires of one's heart. How can a Jew kill a living thing without any benefit to anyone and engage in hunting merely to satisfy "the enjoyable use of his time"? (Rabbi Ezekial Landau in Responsa in Teluskin, 2000).

Fifteenth century philosopher Rabbi Albo (in Zamore, 2011), describes how killing of animals requires cruelty, rage, and the accustoming of oneself to the bad habit of shedding innocent blood. Interestingly, Leviticus (17:13) instructs Jews to pour out the blood of hunted prey and cover it with earth which teaches that hunters should be ashamed and hide the evidence of their killing.

Maimonides (2017) reasoned Jewish dietary laws (discussed in the next section) recognise animals have a soul. Their fear of pain and death and capacity for feeling pain and anguish make them similar to humans. He sees no difference between the pain of people and that of other living beings, "since the love and the tenderness of the mother for her young ones is not produced by reasoning but by feeling, and this faculty exists not only in people but in most living creatures" (Maimonides, 2017, 3:48).

The moral message underlying the biblical emphasis on kindness to animals was interpreted by Maimonidies as illustrating that if the Torah protects birds and animals from grief "how much more careful must we be that we should not cause grief to our fellow men" (Hertz, 1981, p. 843). Rabbi Hertz writes that the theme of compassion for animals is of profound importance for the humanising of people and illustrates that there is an unbroken continuity in the scale of all living creatures, that life is life whether it is an animal's or a human's (Hertz, 1981, p. 854). The former chief Rabbi of Ireland, Rabbi David Rosen explains that compassion as clearly laid out in the Torah and expounded by Jewish sages is "a matter of imbuing ourselves with the right kind of values. If we are insensitive towards animal life, then we desensitise ourselves as human beings. And therefore a truly sensitive human being, compassionate towards other human beings, should be compassionate towards animals" (Rosen in Brook, 2009, n.p).

Modern livestock production, is, in every way, in direct violation of tza'ar ba'alei chayim (the rule against suffering of living creatures). Most farmed animals, including those for kosher consumers, are raised on factory farms suffering in cramped, confined, cruel spaces, drugged, mutilated, burned, tortured and denied access to fresh air, water, sunlight, exercise and any enjoyment. Consequently, a number of Jewish authorities have described the injunctions of $t z a^{\prime}$ ar ba'alei chayim as requiring adoption of a vegan diet.

For example, the Israeli Rabbi Asa Kesiar argues the slaughter of animals in contemporary times violates tza'ar ba'alei chayim and therefore no animal product can be considered kosher. Rabbi Kesiar teaches that the questions we should ask ourselves are: "Can we drink milk which was obtained while transgressing tza'ar ba'alei chayim? Can we eat kosher eggs which were laid while the chickens 
suffered severe abuse? The answer requires us to look inwardly with integrity and honesty, and the answer is of course not. According to Jewish law, we are not allowed to purchase meat, dairy and eggs which came from the industry" (Keisar, 2020, n.p.). The Israeli Rabbi Simchah Roth argues contemporary slaughter "constitutes cruelty to animals - tza'ar ba'alei chayim - which is forbidden by the Torah" (in Jewish Vegetarian Society, 2013, n.p.). Similarly, the American Rabbi Geoffrey Claussen believes tza'ar ba'alei chayim must lead to "committing to a vegan diet and boycotting the animal agriculture industry" (Claussens, 2019, p. 12). "Judaism regards animals as sentient beings. They may not think or speak, but they do feel, ... and cruelty as far as possible should be avoided" wrote Rabbi Lord Jonathan Sacks (2019, n.p.).

Meat-eating was originally entirely proscribed. Once a temporary concession was granted, because an animal must die, which could be in contravention of tza'ar ba'alei chayim, the Torah placed strict limits on the meat-eating via the laws of Kashrut, perhaps the most fundamental expression of observance throughout the ages (Engelmayer, 2019 n.p.). A brief description of the laws of Kashrut follows.

\section{KASHRUT - DIETARY LAWS AS ATONEMENT FOR FLESH-EATING}

Discussion so far has shown Adam and Eve's original diet consisted of fruits, grains and nuts (Genesis 1:29). After their fall, G-d added vegetables — or the "herb of the field" - to humankind's diet (Genesis 3:18). Only after The Flood were Noah and his descendants given reluctant divine permission to consume certain animal products governed by strict dietary laws to direct human behaviour through the corridor of time back to an era of peace amongst all humans and animals. Interestingly, while humanity was granted permission to eat meat, this was accompanied by the curse that the animals created to be Adam's companions fear and dread humans: "And the fear of you and the dread of you shall be upon every beast of the earth, and upon every fowl of the air, upon all that moveth upon the earth, and upon all the fishes of the sea; into your hand are they delivered" (Genesis 9:2-3).

Genesis should thus be considered in conjunction with Leviticus 11 where the laws of kashrut - the Jewish dietary laws and restrictions that accompany the permission to eat meat - are laid out. Translated from Hebrew, the word kasher means "fit", and the laws of Kashrut state out which foods are appropriate or fit to eat. The Kashrut laws are hence the foundation for observance of kosher (Shimoni, 2019).

Kashrut laws are numerous and complex but rest on a few key principles. These are that:

- Only certain types of mammals, birds and fish meeting specific criteria are kosher and those that do not meet these criteria (such as pork and shellfish), are forbidden.

- Slaughter is a clear and very specified process.

- Blood may never be consumed ("flesh with the life thereof, which is the blood thereof, shall ye not eat" (Genesis 9:4)).

- Meat and meat derivatives must never be mixed with milk and milk derivatives (based on the Biblical law prohibiting boiling a kid in the milk of its mother - Exodus 23:19, 34:26; Deuteronomy 14:21).

Conversely, produce that grows from the earth - all species of fruits, grains and vegetables - are always permissible and may be eaten without restriction (although consumption may be regulated by tithing and maturation). Significantly, there is no specific Jewish blessing for meat as there is for bread, fruit, wine and vegetables.

The rationale for most kashrut laws is not explicitly stated. Whilst some scholars suggest they are tests of obedience, or laws for practical, philosophical or hygienic reasons, there is strong suggestion the many laws associated with preparation and consumption of meat are a reprimand and an elaborate 
apparatus to keep alive a sense of reverence for life with the aim of eventually leading people away from their meat-eating habit (Kook, 1978, p. 319).

This idea is echoed by Torah commentator Solomon Efraim Lunchitz: "What was the necessity for the entire procedure of ritual slaughter? For the sake of self-discipline. It is far more appropriate for man not to eat meat; only if he has a strong desire for meat does the Torah permit it, and even this only after the trouble and inconvenience necessary to satisfy his desire. Perhaps because of the bother and annoyance of the whole procedure, he will be restrained from such a strong and uncontrollable desire for meat" (in Chill, 1974, p. 400). Rabbi Shlomo Riskin, a leading Israeli Orthodox rabbi, explains that: "The dietary laws are intended to teach us compassion and lead us gently back to vegetarianism" (in Schwartz, n.d., para. 12). Numerous biblical and philosophical references describe the moral return to vegetarianism as a virtue of such great value that it cannot be lost forever.

Jewish sages and mystics describe how in the forthcoming enlightened era no one shall hurt nor destroy another living creature and people's lives will not be supported at the expense of the lives of animals: "In the messianic age, the biblical ideal to which all humankind should strive to return, no meat shall be eaten - neither by not by people or other animals" (Green, n.d., p. 1). Likewise, "none shall hurt nor destroy in all of G-d's holy mountain" (Isaiah 11:9).

Humanity's moral imperfection remains a fact in today's world - people are still "ruled by tyranny and falsehood, nationalistic hatreds and jealousies, racial hatred, and family feuds, over which rivers of blood continue to be spilled" (Kook, 1961, p.??). Kook writes "When the animal lust for meat became overpowering, if the flesh of all living things had been forbidden, then the moral destructiveness... would not have differentiated between man and animal...The knife, the axe, the guillotine, the electric current would have felled them all alike in order to satisfy the vulgar craving of... humanity) (Kook, 1978, pp. 318-319).

Until a perfect world is achieved, Kashrut laws are much more than a technical ritual directing Jews what to eat and how. They are a set of injunctions that require an awareness that what one consumes matters and that one must be mindful of one's own diet and dietary practices.

\section{ONE'S OWN HEALTH AND THE HEALTH OF OTHERS}

Jews are commanded to look after health and life through the mandates of sh'mirat haguf (preserving our bodies and health) and pekuach nefesh (saving and protecting lives at almost any cost). Nineteenth century commentator Rabbi Samson Raphael Hirsch explains: "You may not weaken your health in any way or even shorten your life... Therefore, avoid anything that could possibly injure your health" (Hirsch, 2002, Chapter 62, Verse 428).

Two biblical laws are particularly pertinent here: Deuteronomy 21:20 prohibits overeating and over-drinking and Deuteronomy 14:3 disallows ingesting any harmful substance. It follows from these two laws that if there are any substances in food that may be harmful (rather than are outright harmful which is forbidden from the start), we must, at the very least, limit such consumption. This should also apply to red meat being classified by the World Health Organisation (WHO, 2015) as carcinogenic (processed meat) and potentially carcinogenic (fresh meat).

According to the Torah, people adhering to the vegetarian diet prescribed in Genesis 1:29 lived phenomenally long lives before The Flood. After The Flood, as widespread meat eating became more common, human lifespans were markedly reduced. Genesis 5 tells us that Adam, Seth, Enosh, Kenan and Methuselah all lived past their 900th birthdays. After the permission to eat meat is granted, longevity declines precipitously. Abraham, for instance, died at the relatively tender age of 175 (Schwartz, n.d.). This biblical steep decline in longevity among meat-eaters is reflected in contemporary lifestyles where diseases of affluence are fast replacing diseases of poverty. Meat-eating is also contributing to the new emerging zoonotic diseases, such as coronavirus, bird and swine flu as well as other viruses that are cutting short the longevity of human population. 
Numerous scientific studies link animal-based diets directly to multiple, widespread, and often fatal diseases. For example, the WHO's International Agency for Research on Cancer (IARC) considered more than 800 studies that investigated associations of more than a dozen types of cancer with the consumption of red meat or processed meat in many countries and populations with diverse diets. This research, which took place over 20 years, illustrated that each 50-gram portion of processed meat eaten daily increases the risk of colorectal cancer by $18 \%$ (Bouvard et al., 2015). Data from the same studies suggest that the risk of colorectal cancer could increase by $17 \%$ for every 100 -gram portion of red meat eaten daily (Bouvard et al., 2015). A 2017 study by the National Cancer Institute and published in the British Medical Journal found that eating a lot of red meat increases by as much as $26 \%$ a person's chances of contracting a number of diseases other than cancer, including heart disease, stroke, diabetes, infections, kidney disease, liver disease, and lung disease (Etemadi et al., 2017).

Further, non-therapeutic use of antibiotics to prevent disease in the overcrowded conditions in livestock bred in concentrated animal feeding operations and factory farms is increasingly recognised as responsible for the emergence of drug-resistant bacteria and viruses that pose grave threats to human health. According to the Food and Drug Administration (FDA), Department of Health and Human Services, in USA alone, more than 6 million $\mathrm{kg}$ of medically important antibiotic drugs were sold for use on livestock farms in 2018 - representing 52\% of all sales in this class of antimicrobial drugs and a 9\% increase from the previous year (FDA, 2019). Intensive livestock operations and factory farms provide many opportunities for bacterial and viral pathogen exposure (Nadimpalli et al., 2014), building of antimicrobial resistance (Review on Antimicrobial Resistance, 2016) and there are many pathways for bacteria to move from farms into homes, cities and hospitals, including causing potential disease outbreaks, epidemics and pandemics.

Examples include mad cow disease, bird flu, foot and mouth disease, E. coli, salmonella and food poisoning. If there were no poultry industry concludes Michael Greger (2006), there would be no epidemics of bird flu. In fact, even the influenza virus which existed for millions of years as an innocuous intestinal virus of wild ducks turned into a killer because of meat consumption (Greger, 2006).

The meat industry is unhealthy and unsafe. Given the mandates of sh'mirat haguf and pekuach nefesh, reducing or eliminating the consumption of animal products should be considered a Jewish value and more importantly, a requirement, based on health reasons alone. According to Rabbi Alfred Cohen, "[f]ollowing the many precedents prescribed in the Code of Jewish Law, we would have little difficulty in arriving at the conclusion that, if indeed eating meat is injurious to one's health, it is not only permissible, but possibly even mandatory that we reduce our ingestion of an unhealthful product to the minimal level" (Cohen, 1981, p. 61.). Maimonides wrote: "Maintaining a healthy and sound body is among the ways of G-d - for one cannot understand or have knowledge of the Creator if one is ill. Therefore one must avoid that which harms the body and accustom oneself to that which is helpful and helps the body." (Mishneh Torah, Hilchot Deot 4:1). Furthermore, "[a]s it is halachically prohibited to harm oneself and as healthy, nutritious vegetarian alternatives are easily available, meat consumption has become halachically unjustifiable" (Rosen, 1995, p. 54).

\section{FEEDING AND SHARING WITH THE HUNGRY}

Rabbi Steinsaltz (2017) teacher, philosopher, social critic, prolific author and winner of the Israel Prize, emphasised that "providing charity for poor and hungry people weighs as heavily as all the other commandments of the Torah combined" (Talmud: Bava Batra 9a). In fact, the Hebrew word for charity, tzedakah, literally means "justice".

The Torah is explicit in commanding to feed the hungry: "And when you reap the harvest of your land, you shall not reap all the way to the edges of your field, or gather the gleanings of your harvest; you shall leave them for the poor and the stranger" (Leviticus 23:22). In Isaiah (58:7), G-d commands us to "share [our] bread with the hungry and bring the homeless into [our] house". Deuteronomy 
(15:7-10) similarly states: "if there is among you a poor man, one of your brethren...you shall not harden your heart or shut your hand against your poor brother, but you shall open your hand to him, and lend him sufficient for his need, whatever it may be". Jewish sages explain that feeding the hungry is one of our most important responsibilities on earth: "When you are asked in the world to come, 'What was your work?' and you answer: 'I fed the hungry,' you will be told: 'This is the gate of the Lord, enter into it, you who have fed the hungry"” (Midrash to Psalm 118:17).

To help share G-d's abundant harvests with the poor, the Torah issues three instructions to farmers known as Leket, Shik'khah, and Pe'ah. These refer to the three portions of any harvest which a farmer must leave for the benefit of the poor. Leket or "gleanings" refers to the ears of corn which fall to the ground during harvest and were not to be gleaned, but were to be left for the poor (Leviticus 19:9-10, Deuteronomy 24:19). Shik'khah or "forgotten produce" refers to a sheaf forgotten by the farmer which could not be retrieved but had to be left for the poor. Pe'ah or "corners" refers to a corner of the field which must always be left unharvested; it was the property of the poor (Leviticus 19:9-10, Deuteronomy 24:19-21).

The Midrash (ancient commentary, written around the second century, on the Hebrew Scriptures) teaches that G-d says to Israel: "My children, whenever you give sustenance to the poor, I impute it to you as though you gave sustenance to Me... Does then G-d eat and drink? No, but whenever you give food to the poor, G-d accounts it to you as if you gave food to Him" (Midrash Tannaim, Deuteronomy 16:20). On Passover Jews are reminded not to forget the poor: "This is the bread of affliction which our ancestors ate in the land of Egypt. Let all who are hungry come and eat. Let all who are in need come and celebrate the Passover" (Passover Haggadah in Marre, 2005). Jews are even told to feed enemies if they are in need: "If your enemy is hungry, give him bread to eat. If your enemy is thirsty, give him water to drink" (Proverbs 25:21). Judaism teaches involvement and concern with the plight of fellow human beings on so many levels and obliges that we do whatever can be done to help others: "Thou shalt not stand idly by the blood of thy brother" (Leviticus 19:16).

Livestock production and consumption make it impossible to fulfil the Jewish requirement of feeding the hungry and caring about the plight of fellow human beings. Approximately 51 million $\mathrm{km}^{2}$ or $50 \%$ of all habitable land on earth is used for agricultural production; 77 percent of this -40 million $\mathrm{km}^{2}$ - is used for animal agriculture (Ritchie \& Roser, 2019a). This land could comfortably produce enough food for 10 billion vegetarians yet more than half of the world's harvest is used to feed animals instead of people (Buff, 2017). Animal production is incredibly inefficient: "Though 800 million people do not have enough food, livestock are fed more than 60 percent of [the world's] corn and barley, and over 97 percent of [its] soymeal" (Turner, 2018). Livestock requires large amounts of land, food, water and energy to produce, yet takes more energy and protein from their feed than they return in the form of food for people (Eshel et al., 2014). Ten pounds of grain are required to produce one pound of meat; in comparison, land used to grow rice can support 19 times more people than land used to produce eggs (Turner, 2018). Six thousand litres of water are required to produce one kilogram of chicken, more than double the amount of water needed to produce one kilogram of cereals (Mekonnen \& Hoekstra, 2012). It will be impossible to achieve the UN Sustainable Development Goal 2 Zero Hunger (UN, 2015) on a diet rich with animal-based foods.

Wise and responsible reorientation and utilisation of resources, in particular reduction or cessation of production and consumption of livestock and animal products, could enable humanity to address global hunger and poverty. Yet again, veganism presents as the only option to addressing the Jewish, biblical, religious injunction to feed the hungry and care for fellow humankind.

\section{PROTECTION OF THE ENVIRONMENT AND CONSERVATION OF RESOURCES}

Bal Tashchit (translated as "do not destroy") is the prohibition to waste or destroy resources - one of the most basic ethical principles in Jewish law. It is rooted in the biblical law of Deuteronomy 20:19-20, an injunction which prohibits cutting down fruit trees when laying siege to a city in the 
context of war. The sages concluded that in a situation of war, where human life is in danger, it is prohibited to cut down a fruit tree - under normal circumstance, the idea of destroying anything that provides sustenance is even greater!

Rabbi Hirsch, one of the greatest Orthodox rabbis of the 19th Century, considers the concept of bal tashchit - the prohibition against wasting and wanton destruction - to be the most basic Jewish principle of all, expressing an essential limitation and discipline on our own personal will and ego. He explains: "Accordingly when we preserve the world around us, we act with understanding that G-d owns everything. However when we destroy it, we are worshipping the idols of our own desires indulging only in self-gratification and forgetting if not denying the One Source of all. By observing the discipline of this prohibition we restore harmony between ourselves and the world around us and above all consciously respect the transcendent Divine Will which we place above our own selfish interests" (Rosen, 2016, n.p.).

Even the Jewish Sabbath - the day of rest so central to Jewish law and life-is seen as a weekly restoration of the natural relationship, both in relation to the Divine and in relation to our social and ecological environment illustrating the "complete harmony between man and nature, man and man; the idea of the anticipation of the messianic time..." (Fromm, 2013, p. 218). In Leviticus 25:23, Hashem says: "For the earth is mine and you are sojourners and temporary resident in it with me" which dictates that we conduct ourselves in as tenants in this world - a world that belongs to its creator. Further, "they rejoice in the destruction of the world, and they destroy themselves..." (Proverbs 17:5).

Animal agriculture and consumption of animal products is one of the primary causes of environmental devastation, including misuse of natural resources, land, air and water pollution, global warming and rain forest destruction. It is the primary driver of climate change - the greatest, and possibly existential danger to face humanity and the earth. Currently, 27\% of the available land mass on this planet is used for livestock grazing and feed compared to only $7 \%$ for crops produced for direct human consumption (Ritchie \& Roser, 2019b). Further comparisons that show the staggering misappropriation of land by the livestock sector can be made with forests which have been reduced to only $26 \%$ of the available land and built-up areas and infrastructure which occupy only $1 \%$ of the planet's landmass (Ritchie \& Roser, 2019b). Hence, it is not the demand for human settlements that drives the eradication of native vegetation and demise of biodiversity, but the push to satisfy human gluttony and desire for animal proteins. As food is ultimately consumed for energy, beef herds require $120 \mathrm{~m}^{2}$ per 1000 kilocalories compared to less than $2 \mathrm{~m}^{2}$ for cassava, groundnuts, wheat, rye, apples, soy beans (tofu), potatoes, root vegetables, rice and maize (Poore \& Nemecek, 2018). All other animal-based foods have higher land demands than plant-based options (e.g. lamb and mutton require $117 \mathrm{~m}^{2}$, cheese $23 \mathrm{~m}^{2}$ and milk $15 \mathrm{~m}^{2}$ ).

Production and consumption of all livestock and animal products is thus a violation of bal tashchit. If Judaism clearly forbids even the destruction of a tree in wartime, how can destruction of the world's rainforests, species extinction, pollution and depletion of water and land resources and global climate change be justified in order to enjoy a steak? Given the burgeoning plant-based alternatives rendering meat livestock products completely unnecessary and wasteful, now is the time, more than ever to truly respect the earth's Divine ownership which we are not to damage or destroy. We cannot continue to pay for widespread environmental devastation through dietary choices yet continue to claim adherence to bal tashchit.

The ancient commentaries on the book of Ecclesiastes (Kohelet Rabbah 7 Section 28) tell how after Hashem created the first human being: "He took him and let him pass before all His works in the Garden of Eden and said to him, 'See my works, how fine and excellent they are. All that I have created for you I have created them. Think upon this and do not corrupt or destroy my world; for if you corrupt it there is no one to set it right after you." In light of the rapid deterioration of human, planetary and animal wellbeing, the original diet described in the Garden of Eden and in the ideal Messianic world to come, namely a rejection of livestock food products, is increasingly urgent goal towards which all people, but particularly Jews, should strive in order to save humanity and the world. 


\section{HEALING THE WORLD}

Tikkun, a signature theme of Jewish tradition, is often translated as "repair" and Olam means "the world". Thus, in Jewish teachings tikkun olam is any activity that improves the world, fixes any damage and brings it closer to the harmonious state for which it was created (Freeman, 2020). Literally it means to do something with the world that will not only fix any damage but also improve on it. Interestingly, the world "olam" also means "hidden" which is often explained as motivation for the need to repair the world so that its creator is no longer hidden within but shines through everything in magnificent and harmonious beauty, the establishment of Godly qualities throughout the world (Jacobs, 2007).

Participating in livestock production and consumption is taking part in the destruction of the beauty, health and functioning of the world. The 2019 Assessment of Global Biodiversity and Ecological Services concluded that: "The biosphere, upon which humanity as a whole depends, is being altered to an unparalleled degree across all spatial scales. Biodiversity - the diversity within species, between species and of ecosystems - is declining faster than at any time in human history" (IPBES, 2019, p. 10) with livestock being a major driver. Livestock grazing alone occurs on $25 \%$ of the planet's ice-free lands, including $70 \%$ of the most vulnerable to erosion soils of the drylands (IPBES, 2019). Furthermore, 90\% of the cleared Amazon rainforest land since 1970 has been for livestock grazing (PETA, 2020). This continued destruction of the pristine habitats means that there is less room for wildlife, native species, birds' songs, flying insects, wild flowers, untamed exotic animals, abundant green vegetation, pristine clean air and natural beauty...

Tikkun olam is described as the mission of every human being - a mission where even small deeds may bring the world to the resolution for which it has yearned since its creation. Maimonides (2017, n.p.) wrote that: "every person should see himself and the entire world as in a delicate balance, whereby any one deed can tip himself and the entire world towards the good..." This is based on the belief that the world has been designed with such precision that its every detail is essential to its perfection. Any one piece of the puzzle may be that crucial piece that brings completeness to every other piece and to the whole (in Freeman, 2020). According to Rabbi Freeman tikkun olam is the entire purpose of humanity's creation - and every human activity either delays or furthers tikkun olam - the repair of the world.

According to Rabbi Freeman, the three most important changes in behaviour humanity needs to experience in order to achieve tikkun olam are individual responsibility, a higher awareness and a sense of urgency. Failing which, the value of human life, its meaning and purpose are nothing more than an absurd, destructive, carbon-consuming mechanism. It is certainly vital to ensure the sustainability of life and function as more than mere destructive mechanisms. Through the way we eat and what we eat we may either bring the world closer to the ultimate state for which Jews believe it was created or participate in its further destruction. The Talmud tells us that every person is an entire world, that each one of us must think of ourselves as responsible for the entire world. Although the concept of tikkun olam can be dated back to 10-220 CE, the modern idea is of human responsibility for the welfare of society at large and fixing what is wrong with the world (Shatz et al., 1997).

\section{CONCLUSION}

Modern livestock production has resulted in environmental and human consequences which contravene the fundamental Jewish mandates of tza'ar ba'alei chayim, bal tashchit (do not destroy); sh'mirat haguf (preserving our bodies and health), pekuach nefesh (saving and protecting lives at almost any cost), sharing food with the hungry and tikkun olam (repair the world). The nuanced position presented by Judaism - that eating meat is a concession to human carnivorous urges but not our highest level - suggests the Bible offers many levels of spiritual practice. In light of the animal, human and environmental impacts of modern livestock production and consumption, and in keeping with the stories, interpretations, commentaries, injunctions and guidances of the Hebrew bible, a return to a 
vegan lifestyle, as originally intended in the Garden of Eden, offers a spiritually-directed and sacred way to live consistently with biblical instruction and simultaneously actively, yet non-violently, oppose daily and brutal human, animal, planetary and environmental welfare violations caused by meat production and consumption. Veganism will facilitate fulfilment of tikkun olam, allowing humanity to participate as pioneers of a healing and repairing world and the vanguard of the messianic era. Judaism is a living religion and a faith of action and Jews believe they should contribute to the overall holiness of the world.

With people increasingly making food choices based on their value systems, and the catering businesses adjusting to such requirements (Fischer, 2016), it is important to also understand the foundations of our human diets. In this paper, we specifically examined the Jewish religion, but similarities and restrictions on animal-based food consumption can be found in many other religions. In the past, moral and religious judgements about food may have been applicable to only specific sections of the global human population. This however has changed. Our global food production, distribution and consumption systems are impacting every living being on this planet through climate change, biodiversity loss, pollution, uncontrolled use of natural resources and new emerging diseases. It is time to draw on the spiritual wisdom of Judaism and all religions about how we produce and consumer food and generally live in and contribute to the wellbeing of this world.

Judaism, as illustrated in so many prayers, talks about "we", "us" and "our", recognising a global community. Irrespective of what is your spiritual world, we are all part of one planet, one global human community. What we do and how we do it, has a broader impact and ripple effect. What we eat, and how we produce our food are no exception. If we draw on the spiritual wisdom of Judaism and other religions to live a more connected, aware, mindful and spiritual life, we are more likely together to face a future filled with hope and positive outlooks for this life and the ones to come. 


\section{REFERENCES}

Appell, V. S. (2020). Why do some Jews write “G-d" instead of “God”? https://reformjudaism.org/learning/ answers-jewish-questions/why-do-some-jews-write-g-d-instead-god

Australian Jewish News. (2019). Global Jewish population hits 14.7 million. https://ajn.timesofisrael.com/ global-jewish-population-hits-14-7-million/

Bouvard, V., Loomis, D., Guyton, K. Z., Grosse, Y., El Ghissassi, F., Tallaa, L. B., Gula, N., Mattock, H., \& Straif, K. (2015). Carcinogenicity of consumption of red and processed meat. The Lancet. Oncology, 16(16), 1599-1600. doi:10.1016/S1470-2045(15)00444-1 PMID:26514947

BrookD. (2009). Tikkun. https://www.tikkun.org/?s=Daniel+Brook

Buff, E. (2017). Can we solve world hunger and feed 9 billion people just by eating less meat? One Green Planet. https://www.onegreenplanet.org/environment/world-hunger-population-growth-ditching-meat/

Caro, J. (1564). Shulchan Aruch [Code of Jewish Law]. Hebrew Publishing.

Chill, A. (1974). The Mitzvot: The Commandments and their rationale. Bloch Publishing.

Claussen, G. D. (2019). Musar and Jewish veganism. In J. Labendz \& S. Yanklowitz (Eds.), Jewish veganism and vegetarianism: Studies and new directions (pp. 210-211). SUNY Press.

Cohen, A. (1981). Vegetarianism from a Jewish perspective. Journal of Halacha and Contemporary Society, 1(2), 38-63. http://ethics.rabbinics.org/Cohen_Vegetarianism.pdf

DellaPergola, S. (2018). World Jewish Population, 2018. In A. Dashefsky \& I. Sheskin (Eds.), American Jewish Year Book 2018. Springer. doi:10.1007/978-3-030-03907-3_8

Engelmayer, S. (2019). More meat to chew on - then again, maybe not. Jewish Standard/Times of Israel. https:// blogs.timesofisrael.com/more-meat-to-chew-on-then-again-maybe-not/

Eshel, G., Shepon, A., Makov, T., \& Milo, R. (2014). Land, irrigation water, green- house gas, and reactive nitrogen burdens of meat, eggs, and dairy production in the United States. Proceedings of the National Academy of Sciences of the United States of America, 111(33), 11996-12001. doi:10.1073/pnas.1402183111 PMID:25049416

Etemadi, A., Graubard, B. I., Inoue-Choi, M., Dawsey, S. M., \& Abnet, C. C. (2017). Mortality from different causes associated with meat, heme iron, nitrates, and nitrites in the NIH-AARP Diet and Health Study: Population based cohort study. BMJ (Clinical Research Ed.), 357, j1957. doi:10.1136/bmj.j1957 PMID:28487287

Fischer, J. (2016). Markets, religion, regulation: Kosher, halal and Hindu vegetarianism in global perspective. Geoforum, 69, 67-70. doi:10.1016/j.geoforum.2015.12.011

Food and Drug Administration (FDA). (2019). 2018 Summary Report on antimicrobials sold or distributed for use in food-producing animals. Department of Health and Human Services, USA. https://www.fda.gov/ media/133411/download

Freeman, T. (2020). What is Tikkun Olam? Chabad-Lubavitch Media Centre. https://www.chabad.org/library/ article_cdo/aid/3591946/jewish/Tikkun-Olam.htm

Fromm, E. (2013). The forgotten language: An introduction to the understanding of dreams, fairy tales, and myths. Open Road Media.

Green, J. (n.d.). Chalutzim of the Messiah-The Religious Vegetarian Concept as Expounded by Rabbi Kook. Lecture given in Johannesburg, South Africa.

Greger, M. (2006). Bird flu: A virus of our own hatching. Lantern Books.

Hertz, R. J. H. (Ed.). (1981). The Pentateuch and Haftorahs (2nd ed.). Soncino Press.

Hirsch, S. R. (2002). Horeb: A philosophy of Jewish laws and observances (7th ed.). NeJudaica Press.

Intergovernmental Panel on Biodiversity and Ecological Services (IPBES). (2019). The global assessment report on biodiversity and ecosystem services: Summary for policymakers. https://ipbes.net/sites/default/files/inline/ files/ipbes_global_assessment_report_summary_for_policymakers.pdf 
Jacobs, J. (2007). The history of “Tikkun Olam". Zeek: A Jewish Journal of Thought and Culture. http://www. zeek.net/706tohu/

Jewish Virtual Library. (2020). Rabbi Shlomo Yitzchaki (Rashi). https://www.jewishvirtuallibrary.org/rabbishlomo-yitzchaki-rashi

Keisar, A. (2020). Veganism and Kashrut. https://asakeisar.com/en/veganism-and-kashrut/

Kook, A. I. (1961). A vision of vegetarianism and peace (D. Cohen, Ed. \& J. Rubenstein, Trans.). Boys Town Press.

Kook, A. I. (1978). Fragments of light: A view as to the reasons for the Commandments. In B. Z. Bokser (Ed.), The lights of penitence, the moral principles, lights of holiness, essays, letters, and poems (pp. 316-321). Paulist Press.

Maimonides, M. (2017). Guide for the perplexed. Kindle Edition.

Marre, P. (2005). The Golden Haggadah - First Responses. British Library. https://www.bl.uk/learning/cult/ inside/corner/first/responses.html

Mekonnen, M. M., \& Hoekstra, A. Y. (2012). A global assessment of the water footprint of farm animal products. Ecosystems (New York, N.Y.), 15(3), 401-415. doi:10.1007/s10021-011-9517-8

Nadimpalli, M., Rinsky, J. L., Wing, S., Hall, D., Stewart, J., Larsen, J., Nachman, K. E., Love, D. C., Pierce, E., Pisanic, N., Strelitz, J., Harduar-Morano, L., \& Heaney, C. D. (2015). Persistence of livestock-associated antibiotic-resistant Staphylococcus aureus among industrial hog operation workers in North Carolina over 14 days. Occupational and Environmental Medicine, 72(2), 90-99. doi:10.1136/oemed-2014-102095 PMID:25200855

People for the Ethical Treatment of Animals (PETA). (2020). Meat and the environment. https://www.peta.org/ issues/animals-used-for-food/meat-environment/

Pick, P. (n.d.). The source of our inspiration. Jewish Vegetarian Society Paper.

Poore, J., \& Nemecek, T. (2018). Reducing food's environmental impacts through producers and consumers. Science, 360(6392), 987-992. doi:10.1126/science.aaq0216 PMID:29853680

Raphaely, T., \& Myerson, A. (2019) Australia: Experiences of a vegan in the Australian Jewish community. In C. J. S. De Backer, M. L. Fisher, J. Dare \& L. Costello (Eds.), To eat or not to eat meat: How vegetarian dietary choices influence our social lives (pp. 49-58). Rowman \& Littlefield.

Review on Antimicrobial Resistance. (2016). Tackling drug-resistant infections globally: Final report and recommendations. https://www.biomerieuxconnection.com/wp-content/uploads/2018/04/Tackling-DrugResistant-Infections-Globally_-Final-Report-and-Recommendations.pdf

Ritchie, H., \& Roser, M. (2019a). Crop yields. Our World in Data. https://ourworldindata.org/crop-yields

Ritchie, H., \& Roser, M. (2019b). Land use. Our World in Data. https://ourworldindata.org/land-use

Rosen, D. (1995). Vegetarianism: An Orthodox Jewish perspective. In R. Kalechofsky (Ed.), Rabbis and vegetarianism: An evolving tradition (pp. 53-60). Micah Publications.

Rosen, D. (2016). Judaism and human environmental responsibility. Kaichid Dialogue Centre. https://www. kaiciid.org/news-events/news/judaism-and-human-environmental-responsibility-\%E2\%80\%93-rabbi-david-rosen

Sacks, J. (2020). Animal welfare (Ki Teitse 5779). https://rabbisacks.org/animal-welfare-ki-teitse-5779/

Schwartz, R. H. (2001). Judaism and vegetarianism (3rd ed.). Lantern Books.

Schwartz, R. H. (n.d.). Veganism and the Jewish dietary laws. https://www.jewishveg.org/schwartz/dietlaws.html

Sears, D. (2014). The vision of Eden: Animal welfare and vegetarianism in Jewish law and mysticism. Orot.

Shatz, D., Waxman, C. I., \& Diament, N. J. (1997). Tikkun olam: social responsibility in Jewish thought and law. Rowman \& Littlefield Publishers.

Shimoni, G. (2019). Jewish dietary laws: Understanding the rules behind Kosher observance in Judaism. The Spruce Eats. https://www.thespruceeats.com/jewish-dietary-laws-2121753 
Steinsaltz, A. E.-I. (2017). Bava Batra 9a-b: The importance of giving charity. The Aleph Society. https:// steinsaltz.org/daf/bavabatra9/

Turner, L. (2018). How eating less meat can reduce poverty. The Borgen Project. https://borgenproject.org/tag/ eating-less-meat-can-reduce-poverty/

United Nations. (2020). United Nations Department of Global Communications 2020 Holocaust Remembrance Calendar of Events. https://www.un.org/en/holocaustremembrance/2020/calendar2020.shtml

United Nations (UN). (2015). Sustainable Development Goals, Goal 2, Zero Hunger. Department of Economic and Social Affairs. https://sustainabledevelopment.un.org/sdg2

Willett, W., Rockström, J., Loken, J., Springmann, B., Lang, M., Vermeulen, T., Garnett, S., Tilman, T., De, D., Clerck, F., Wood, A., Jonell, M., Clark, M., Gordon, L. J., Fanzo, J., Hawkes, C., Zurayk, R., Rivera, J. A., De Vries, W., \& Murray, C. J. L. et al. (2019). Food in the Anthropocene: The EAT-Lancet Commission on healthy diets from sustainable food systems. Lancet, 393(10170), 447-492. doi:10.1016/S0140-6736(18)317884 PMID:30660336

World Health Organisation (WHO). (2015). Q\&A on the carcinogenicity of the consumption of red meat and processed meat. https://www.who.int/news-room/q-a-detail/q-a-on-the-carcinogenicity-of-the-consumption-ofred-meat-and-processed-meat

Zamore, M. L. (Ed.). (2011). The sacred table: Creating a Jewish food ethic. CCAR Press.

\section{ENDNOTES}

This is the abbreviation used in Judaism as a sign of respect and "the custom comes from an interpretation of the commandment in Deuteronomy 12:3-4 regarding the destruction of pagan altars" (Appell, 2020, n.p.). Although some argue that with computers and in English this rule does not apply, the style of the article adheres to this convention.

2 We use gender-neutral language in the main text, but in quotes adhere to the original translations. 